\title{
Identifying Ethnomathematics in the Old Mosque of Tosora
}

\author{
Negara Mangkubumi K. \\ SMP Negeri 2 Sengkang, Wajo, South Sulawesi, Indonesia \\ negarak55@guru.smp.belajar.id
}

\begin{abstract}
The superficial understanding and application of cultural values in the life of a pluralistic community is the main reason to conduct this research as a way to introduce the importance of national identity to students through mathematics learning. The provision of real-life problems in this study is expected to enhance the relationship between reality and mathematical knowledge. The old mosque of Tosora in Wajo can be an alternative to introduce mathematical activities based on local wisdom (ethnomathematics). This is qualitative descriptive research using a case study. Data were obtained through interviews, observation, and documentation. Data triangulation was used to check the validity. Furthermore, the data were analysed through Spradley model based on domain analysis and taxonomic analysis. The results showed that the old mosque of Tosora contains some mathematical concepts, mainly geometry. In addition to the philosophy of the building, the four pillars namely panrita (wise and honest), warani (brave), macca (intelligent), and sugi (rich) become the focal principles of Buginese's life.
\end{abstract}

Keywords: Ethnomathematics, Tosora Mosque, architecture, geometry.

\section{Introduction}

Global change is not always about a massive change of mankind, but more about the changing aspect of human individuality as an asset of human wealth (Tilaar, 1997). Furthermore, it is obvious that instead of destroying nation's culture, globalization introduces a new diverse global culture that contributes to the birth of a more widespread international cultural mosaic. In the context of education, Tilaar (1997) further explained that globalization is underpinned by the spirit of unlimited information. This results in a cross-cultural process that brings together cultural values, thus making it necessary to reproduce knowledge for future development.

Indonesia is renowned for its abounding natural resources and cultural diversity that spread across the archipelago and have become a powerful attraction to the foreign tourists. However, this wealth is mainly disrupted by the rapid digitalization and technological development. These developments in all walks of life have gradually eroded the national cultures, which may lead to self-identity and moral crises of Indonesians. Such disconcerting fact is attributed to the shallow understanding and implementation of cultural values in a plural community (Wahyuni et al., 2013).

Education and culture are inseparable from daily life. However, cultural values are less implemented in the formal and non-formal education sectors in any levels. Amir \& Marzuki (2021) held the view that the cultural inheritance is an important part of a community. It has a fundamental value for the moral development of humans as members of society. Furthermore, it was conveyed that cultural inheritance can take place through a learning process, mainly 
through education that transforms cultural values. The inculcation of sublime characters for students at an early level is necessary, one of which is through mathematics learning.

An individual's competency to think and to act depends upon his/her competency to interact and to communicate with his/her cultural context (Forbes, 2018). Good communication skills as part of the interaction in a student's learning environment will make it easier to convey ideas. In mathematics learning, this ability serves as an important element in higher order thinking skills. To get used to cognitive level of thinking highly correlates with the understanding of mathematical objects. Four mathematical objects, namely facts, concepts, principles, and skills are embedded in the human mind (Zaenuri \& Dwidayanti, 2018). Mathematical concepts in daily life are seen in human creations, involving many activities like finding, drawing, measuring, and designing. These activities are based on interest and intention, which reflects cultural traditions and values through buildings. The results of preference and intention are developed into a cultural civilization in the form of buildings, such as temples, mosques, churches, houses, and others as human cultural constructions resulting from mathematical activities.

Mathematical explanation is included in the cultural element through the application of ethnomathematics. It acts as pedagogical action in learning mathematics, returns sense of involvement, and increases creativity in doing mathematics (D'Ambrosio, 2007). According to Rosa \& Orey (2016), ethnomathematics is growing as an appropriate alternative to traditional learning in terms of history, philosophy, cognitive, and pedagogics. It becomes an entry point that focuses on legitimizing students' knowledge that comes from experiences built in their own way. In line with this matter, Risdiyanti \& Charitas (2020) articulated that ethnomathematics helps teachers and students to understand mathematics in the context of ideas, ways, and practices used in everyday life which will ultimately encourage the understanding of academic mathematics at school.

Patrianto \& Rahiem (2019) held another notion that ethnomathematics has an influence in the formal school through mathematics learning and provides the necessary contextual meaning to a lot of abstract mathematical concepts. This learning process starts from some basic learning activities such as adding, subtracting, counting, and measuring, which can attract students' learning attention. Activities that involve locating and designing can stimulate their critical and creative abilities. Several types of games in learning activities that are practiced by children, both in the form of spoken language, written symbols, pictures, and physical objects will certainly provide meaningful learning experience. Game enables students to learn a new experience to help them comprehend the materials.

Freudenthal (2012) claimed that mathematics, to be of human value, must relate to reality, remain close to children, and must be relevant to society. The potency of cultural-based local wisdom becomes an alternative that can be integrated in mathematics learning. This is in opposition to mathematics learning that is considered to be less varied, more theoretical, less contextual, and more abstract, which affects students' psychological aspect. The stiffness, formality, and numerical oriented characteristics make mathematics far from the real-world context. What students get during the learning process shows less of contextual connection to social, cultural, and historical issues. Therefore, formal education should take the combination of mathematics learning and culture into account to bridge mathematics and the local wisdom 
and culture that is the basis of daily life. Suastra et al. (2017) stated that local wisdom is defined as the truth that has become a tradition.

In regards with cultural context, Tosora is one of the historical areas in Majauleng, Wajo, South Sulawesi. Tosora is derived from Bugis word To Sore, which is roughly translated as people who have just arrived by air travel or have just landed (Proyek Pemugaran dan Pemeliharaan Peninggalan Sejarah dan Purbakala Sulawesi Selatan, 1984). Wajo is well known as the old city, and thus holds various traces of the Wajo Kingdom, a prolonged legacy of Cinnotabi Kingdom. Latenri Bali was noted in the history as the first king, who was granted the title as Batara Wajo I. It was him who changed the name of the city of Cinnotabi to Wajo (Badja, 2012). Upon the arrival of Islam in Wajo, Tosora started to become the centre of Islamic propagation and the capital of Wajo Kingdom. This fact is marked by many building relics in the old mosque, mushalla (an open space for praying), gaddonge (flower buildings), and ancient tombs as the evidence of Islamic development (Duli, 2012).

Wajo people highly adopt Bugis culture. A widely held notion believed that the behaviour of leaders, systems, and ethos were the determinants of one's life. This principle was clearly marked by the presence of old mosque of Tosora in a rectangular shape. The shape adheres to the philosophy of the origin of human life: earth, fire, water, and wind. The material used for the old mosque of Tosora consisted of limestone and rocks mixed with shell fossils, sand, and brick (Proyek Pemugaran dan Pemeliharaan Peninggalan Sejarah dan Purbakala Sulawesi Selatan, 1984). The adhesive materials were composed of sand and brown limestone, which symbolized the colour of sulapa appa (the four principles of Buginese life). For Buginese, black, red, white, and yellow represent land, fire, water, and wind respectively.

To actualize cultural-mathematical integrated learning, it is important to explore the construction of the historical heritage sites or local cultures as a way to relate it with mathematical concept. Some studies have tried to relate the exploration of local cultural heritage. Huda (2018) contributed to the discovery of geometry elements, such as square planes and solid figures. Another study, Utami (2018) disclosed the mathematical activity in the Lampung traditional house, which contains the mathematical concepts of one-dimensional geometry, two-dimensional geometry, three-dimensional geometry, geometrical transformation, odd numbers, even numbers, and rational numbers. A similar study by Putri (2017) revealed the existence of mathematics elements in the traditional tambourine art, such as geometrical concepts and numeration techniques that produce harmonious tone patterns.

It is not only cultural context that is needed in learning mathematics, but also character building. As stated in the 2013 Indonesian Curriculum, character and etiquette are required during the learning. Thus, it is important for this study to identify religious heritage sites of Tosora old mosque in Wajo, South Sulawesi through mathematical concepts since it is related to these curriculum requirements. In junior high school, quadrilaterals (grade 7), two dimensional shapes (grade 8), and three-dimensional shapes (grade 9) are relevant to students' daily lives. The application of mathematical concepts such as area, volume, line, angle, and various other concepts is found in community activities. This fact indicates that the cultural elements have mathematical values to be taught to students contextually. Tracing certain parts of the historical buildings can serve as a concrete example of learning mathematics for the 
application of mathematical concepts that produce an aesthetic, so that learning in schools becomes more realistic.

Based on the previous explanation, the researcher was interested in conducting a study involving the identification of ethnomathematics within the heritage site of the old mosque of Tosora. The core of the problem discussed in this study is based on a research question: "How can we use ethnomathematics to reveal the cultural values of the heritage site of the old mosque of Tosora?"

In terms of theoretical benefit, this study aims to compile information regarding the connection between mathematics and the heritage site of the old mosque of Tosora. In addition, this study is also expected 1) to improve interest and motivation to learn mathematics outside the classroom; 2) to introduce an innovation for mathematics learning and cultural to the students; and 3) to construct a reference for developing mathematics learning on the realistic potential of mathematics in cultural contexts.

\section{Methods}

This research used descriptive research with a case study method. The case study is used to provide a detailed description of the background, characteristics, activities, specificity or uniqueness that characterizes the case or the status of a particular individual, group or community, as a way to generalize the findings into general matters (Agasi \& Wahyuono, 2016). The two steps in this case study were choosing a cultural object and conducting interviews. The scope of this research is the heritage site of the old mosque of Tosora. The researcher interviewed local people who have knowledge of the history of the old mosque and collected data from these process.

The data were collected from a literature study and observation, documentation, and interview. The description and in-depth analysis about the cultural heritage of the old mosque of Tosora was taken from a fieldwork. The researcher served as the only one to collect data and information from the informant based on an interview guidelines and observation checklist.

The data were then validated by way of triangulation, mainly by utilizing any other forms of data to compare the existing data (Moleong, 2014). The researcher validated the data by comparing interview results from the informants to the previous research findings, , the observations, and documentation.

Collected data were analysed through the Spradley model based on domain and taxonomic analysis (Sugiyono, 2013). Domain analysis was carried out to get general and overall description of the research object based on the category or domain. In this research, the data related to the concepts of mathematics were categorized based on their ethnomathematics categories or domains that have been formulated, for instance in the form of numbers, algebra, geometry, statistics, and so on. Then, of the data were analysed taxonomically to explain the chosen domains in more detail based on the existing mathematical concepts in the old mosque of Tosora in Wajo. The data were presented in a matrix (table). 


\section{Results and Discussion}

The results of data triangulation based on the interviews with research informants related to the old mosque of Tosora are presented in Table 1. Table 1 indicates that based on a religious perspective, Tosora Old Mosque serves as a centre for propagating Islam. In terms of the building design, langkara building or mushalla supports the main mosque, which indicates that the area used to be densely populated. Mushalla served as a place for prayer. In terms of the structural aspect of the building, it is apparent that the building design has applied mathematical concepts, including elements of geometry.

Table 1

Result of Study

\begin{tabular}{|c|c|c|c|c|}
\hline No & Indicator & Results of Interview & $\begin{array}{c}\text { Results of } \\
\text { Observations }\end{array}$ & $\begin{array}{c}\text { Result of } \\
\text { Documentation }\end{array}$ \\
\hline 1 & $\begin{array}{l}\text { The establishment of } \\
\text { Tosora Old Mosque }\end{array}$ & $\begin{array}{l}\text { It was built around 16th } \\
\text { century, when the Wajo } \\
\text { Kingdom was newly } \\
\text { established and the Wajo } \\
\text { citizens started to embrace } \\
\text { Islam. The building } \\
\text { materials were composed } \\
\text { of egg white and limestone. }\end{array}$ & $\begin{array}{l}\text { The history of the old } \\
\text { mosque of Tosora is } \\
\text { explained according to } \\
\text { documentation sources, } \\
\text { including traces of } \\
\text { relics that are estimated } \\
\text { to be hundreds of years } \\
\text { old. }\end{array}$ & $\begin{array}{l}\text { The graves of great } \\
\text { scholars at that time } \\
\text { included the tombs } \\
\text { of several royal } \\
\text { servants. }\end{array}$ \\
\hline 2 & Community activities & $\begin{array}{l}\text { Tosora was the capital of } \\
\text { the Wajo Kingdom as well } \\
\text { as the main centre of } \\
\text { economic activities. } \\
\text { Democracy has been } \\
\text { applied since the presence } \\
\text { of the kingdom and the old } \\
\text { mosque of Tosora. }\end{array}$ & $\begin{array}{l}\text { The mosque is not only } \\
\text { used for worship but } \\
\text { also for economic } \\
\text { activity. Such function } \\
\text { was indicated by the } \\
\text { traces of the langkara. } \\
\text { At that time, it } \\
\text { ssupported the main } \\
\text { mosque. This fact } \\
\text { illustrates that the area } \\
\text { was densely populated. }\end{array}$ & $\begin{array}{l}\text { The existence of } \\
\text { langkara }\end{array}$ \\
\hline 3 & Geometrical aspects & $\begin{array}{l}\text { The building embodied } \\
\text { geometrical shapes, one of } \\
\text { which was the mihrab, a } \\
\text { place for the imam to lead } \\
\text { prayers. }\end{array}$ & $\begin{array}{l}\text { Parts of the mosque } \\
\text { building comprised } \\
\text { mathematical concepts. }\end{array}$ & $\begin{array}{l}\text { The mihrab shape is } \\
\text { slightly curved. } \\
\text { There were square } \\
\text { windows on its left } \\
\text { and right. In } \\
\text { addition, there were } \\
\text { other parts that } \\
\text { concerned with } \\
\text { geometric concepts. }\end{array}$ \\
\hline
\end{tabular}

Badja (2012) revealed that the basic plan of the mosque was a square shape. The inside of the mosque was equipped with a curved mihrab. Mihrab is a semi-circular niche that juts into the front wall of the mosque and shows the direction of qibla, where the imam leads the prayer. 


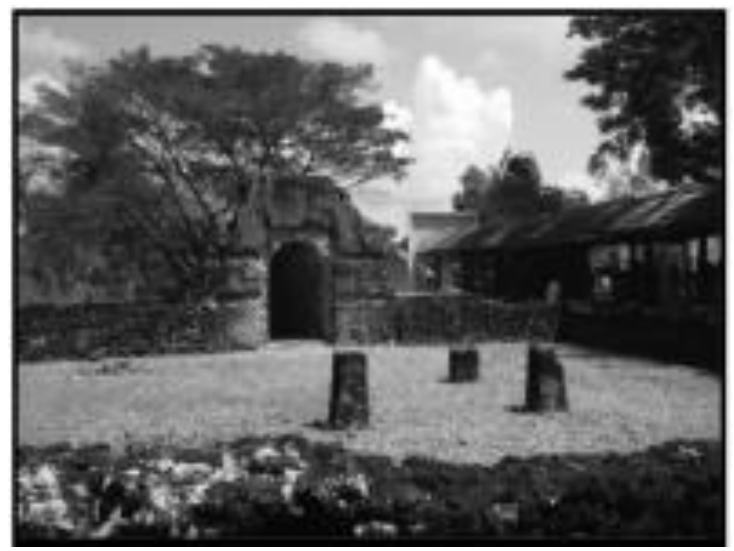

Figure 1. The Tosora Old Mosque (Surur et al., 2017).

In addition, the relic of four pillars of the mosque shows that the the building design not only considers function and aesthetics, but also uses mathematical concepts in its design. In line with Surur et al. (2017) findings, the architectural form is described as a square as illustrated in Figure 1. It is related to the philosophy of the Bugis nobleman, sulapa appa, which means the four principles of life. These four elements serve as life-guidelines to bring improvements in the field of leadership, social, and self-excellence (Yudono et al., 2018).

The roof of the old mosque that was designed in a triangular shape resembled the roof of an old mosque in South Sulawesi. It was also supported by four main pillars as the local characteristics. The four pillars illustrate the qualities that should be possessed by Buginese. Those are panrita (wise and honest), warani (brave), macca (intelligent), and sugi (rich). It was further explained that the qualities must be possessed by Buginese to manifest their living conditions as panrita (wise and honest), warani (bold), macca (intelligent) and sugi (rich) (Surur et al., 2017).

The ethnomathematics categories through observation, documentation, and interviewrevealed that the mosque has mathematics elements. The building, the niche, windows, walls, and pillars are related to geometrical concepts, especially two-dimensional shapes. These elements can be used to connect the mathematics learning at school to the cultural value. Below is the detailed analysis of the building related to the mathematical aspects. 


\section{The Building Foundation}

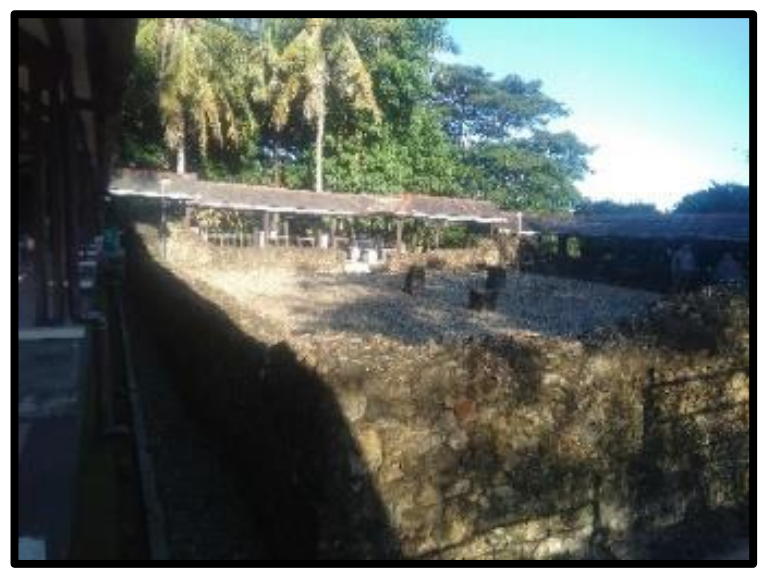

Figure 2. The building foundation of Tosora Old Mosque.

Figure 2 shows the foundation of the old mosque which is in the square shape. The mathematical activities and aspects are as follows.

1. Observing the object, which resembles a square, and studying its elements such as angles, sides, and diagonals.

2. Identifying the following characteristics of a square on the object.

- All sides are equal in length.

- Its four angles are right angle.

- Opposite sides are parallel.

- Each diagonal bisects one to another at right angles. The point is the diagonals intersect and divides each diagonal into two equal parts.

- The two diagonals are in the same length.

- It has four axes of symmetry.

3. Evaluating the area of a square using the formula: side $\times$ side $=s^{2}$.

4. Evaluating the perimeter of a square and finding its formula that is four times its side.

\section{The Niche}

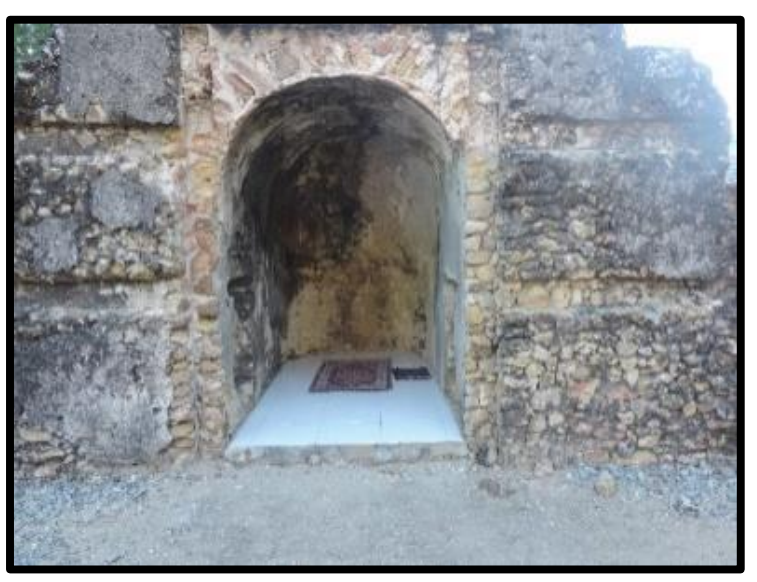

Figure 3. The Niche. 
The niche, as displayed in Figure 3, becomes the object of observation. From twodimensional perspective, it is a compound shape formed by a rectangle and a half-circle. While according to three-dimensional point of view, it is composed of a cuboid and a cylinder, which was cut such that half of the curve surface appears. The mathematical activities and aspects are as follows.

\section{Two-dimensional concept}

To determine the total perimeter of compound of two-dimensional shapes, we need to add the three sides of the rectangle and the circular arc (half of a circle). Therefore, we get the total perimeter equals to $w+(2 \times l)+\pi r$.

2. Three-dimensional concept

Related to this concept, the activity encourages to mention the elements of cuboid; i. e. face, edge, vertex, space diagonal, face diagonal, and diagonal plane and the elements of cylinder, such as the curved surface, height, base, radius, and diameter. To add, we can analyse the compound volume that is $(h \times w \times l)+1 / 2 \pi r^{2} h$ and the compound surface area that is $(l \times w)+2(w \times h)+2(l \times h)+\pi r(r+h)$.

\section{The Corner}

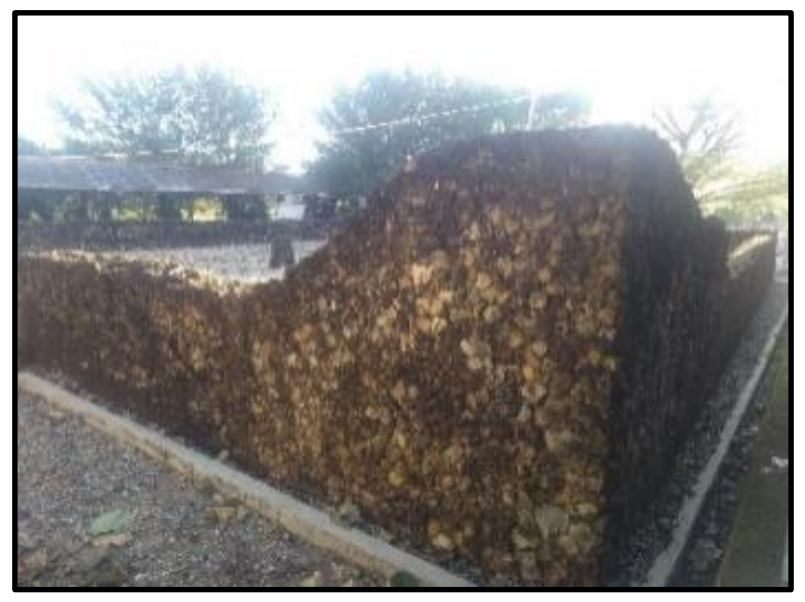

Figure 4. The mosque's corner.

The part of the mosque's corner as in Figure 4 indicates the mathematical concepts of lines and angles as explained in the following activities.

1. Identifying the elements of angles, such as arms, vertex, and ray and pointing out that the right angle is equal to 900 .

2. Pointing out the concept of lines that is two intersecting lines. Two rays, $k$ and $l$, are said to be intersected if they have common end point, which is known as vertex. Two intersecting lines have one vertex. 


\section{The Ventilation}

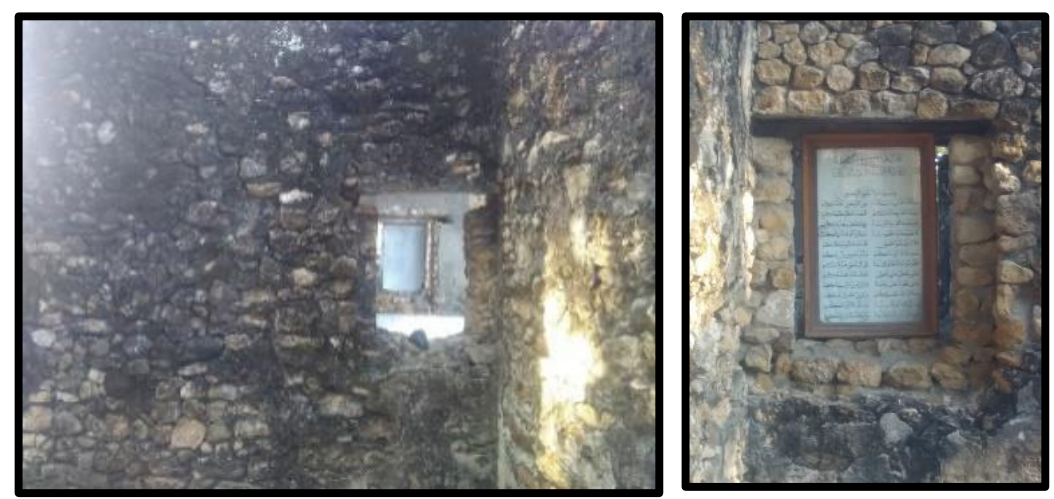

Figure 5. The mosque's ventilation.

There is a ventilation on the mosque as shown in figure 5. It contains the mathematical concepts of two-dimensional shapes, particularly a rectangle.

1. Observing the elements of a rectangle and pointing out its angles, sides, and diagonals.

2. Identifying the following characteristics of a rectangle.

- The four angles are right angle.

- The opposite sides are equilateral, and they are parallel.

- Both diagonals are in the same length and intersect in the middle.

- It has two axes of symmetry.

3. Measuring the perimeter of a rectangle and finding its formula that is twice of the sum of its width and length.

The identified mathematical aspect in the mosque indicates that the ancestors of Wajo people integrated the building design with the cultural philosophy. It makes the mathematical concept in building parts of Tosora Old Mosque as a significant work clearer; the bond indicates cultural activities of the previous society that are still preserved until now. Saputro (2018) explained that concrete and related elements can be used as learning sources to connect the daily experiences of students. It includes students' development in the mathematics learning innovations based on local cultural. Therefore, we can organize mathematics learning outside the classroom.

These activities are expected to improve students' experiences and knowledge on mathematical concepts. By introducing and connecting mathematics with the cultural-based local wisdom, students can expand their knowledge and open their minds to a multidisciplinary course as a way to incorporate mathematics, culture, and history. The learning process can be more fun and more meaningful as it involves contextual problems. It is expected to change the old paradigm of mathematics learning that is only restricted with learning symbols, numbers, or formulas, to the new paradigm of learning mathematics by way of a cultural aspects or civilization. This notion is in line with Adam (2004), who articulated that cultural aspect contributes to seeing mathematics as part of the daily life. These cultural aspects can be developed into a mathematical activity which has meaningful connection and competency. The activity is expected to enable students to form a deeper understanding of mathematical concepts. 


\section{Conclusion}

Based on the result and discussion, these findings indicate that mathematical knowledge can be obtained from many aspects outside of school. One of the possible methods to integrate mathematics and other culture aspects is ethnomathematics that is applicable in the heritage site in Wajo, an old mosque of Tosora. The building not only possesses elements of mathematics but also principles of Buginese's life. This is indicated by the four pillars of the mosque that is in line with sulapa appa value. The philosophy inspires Wajo people to be panrita (wise and honest), warani (brave), macca (intelligent), and sugi (rich).

\section{Acknowledgements}

I would like to express my gratitude to the Wajo Cultural Figure for being the resource person in this research. This study is extensively supported by the Wajo Regency Education and Culture Office and the Principal of SMP Negeri 2 Sengkang for providing permission and opportunities to complete the manuscript.

\section{References}

Adam, S. (2004). Ethnomathematical ideas in the curriculum. Mathematics Education Research Journal, 16(2), 49-68. https://doi.org/10.1007/BF03217395.

Agasi, G. R., \& Wahyuono, Y. D. (2016). Kajian Etnomatematika : Studi Kasus Penggunaan Bahasa Lokal Untuk Penyajian dan Penyelesaian Masalah Lokal Matematika. PRISMA, Prosiding Seminar Nasional Matematika, pp. 527-540. Semarang: Semarang State University.

Amir, R., \& Marzuki, K. (2021). Membangun karakter bangsa melalui kegiatan tradisi appadekko. INOVASI: Jurnal Hasil Pengabdian Masyarakat, 1(1), 17-25.

Badja, A. M. (2012). Situs Tosora sebagai kawasan cagar budaya di kabupaten wajo. Makassar: Balai Pelestarian Cagar Budaya Kementerian Pendidikan dan Kebudayaan.

D'Ambrosio, U. (2007). Peace, social justice and ethnomathematics. The Montana Mathematics Enthusiast, Monograph, 1, 25-34.

Duli, Akin (2012). Kajian terhadap peninggalan budaya awal kerajaan islam di tosora-wajo abad XVII-XVIII. Jurnal Pemikiran Islam, 16(3)

Forbes, W. A. (2018). Using ethnomathematics principles in the classroom: a handbook for mathematics educators. Ontario.

Freudenthal, H. (2012). Mathematics as an educational task. Springer Science \& Business Media

Huda, N. T. (2018). Etnomatematika pada bentuk jajanan pasar di daerah istimewa yogyakarta. $\begin{array}{lllll}\text { JNPM (Jurnal Nasional Pendidikan Matematika), } & 2(2),\end{array}$ https://doi.org/10.33603/jnpm.v2i2.870

Moleong, L. J. (2014). Metode penelitian kualitatif. Bandung: PT. Remaja Rosdakarya.

Patrianto, F \& Rahiem, V.A (2019). Ethnomathematics makes Learning Mathematics more Meaningful. One Asia Community Conference: Strengthening Entrepreneurship in ASIAN Comumunity, pp.117-120. Bandung: FISIP UNPAS Press. 
Proyek Pemugaran dan Pemeliharaan Peninggalan Sejarah dan Purbakala Sulawesi Selatan. (1984). Studi kelayakan bekas ibu kota kerajaan wajo (Abad XVII) di tosora. Departemen Pendidikan dan Kebudayaan.

Putri, L. (2017). Eksplorasi etnomatematika kesenian rebana sebagai sumber belajar matematika pada jenjang mi. Jurnal Ilmiah Pendidikan Dasar UNISSULA, 4(1), 136837. https://doi.org/10.30659/pendas.4.1.

Risdiyanti, I \& Charitas, R (2020). Ethnomathematics (Teori dan Implementasinya: Suatu Pengantar). Bantul: UAD Press.

Rosa, M., \& Orey, D. C. (2016). Innovative approaches in ethnomathematics. In Current and Future Perspectives of Ethnomathematics as A Program, pp. 17-23. Cham: Springer.

Saputro, M. H. (2018). Exploration of geometry concept in traditional tools of dayak tabun. Prosiding Pembelajaran Matematika Menghadapi Era Revolusi Industri 4.0, pp. 397403. Surabaya: Unesa University Press.

Siagian, M. D. (2016). Kemampuan koneksi matematika dalam pembelajaran matematika. MES: Journal of Mathematics Education and Science, 2(1).

Suastra, I. W., Jatmiko, B., Ristiati, N. P., \& Yasmini, L. P. B. (2017). Developing characters based on local wisdom of bali in teaching physics in senior high school. Jurnal Pendidikan IPA Indonesia, 6(2), 306-312. https://doi.org/10.15294/jpii.v6i2.10681

Sugiyono. (2013). Metode penelitian kuantitatif, kualitatif dan R\&D. Bandung: Alfabeta CV.

Surur, F., Wahdaniyah, N., \& Khairah, M. (2017). Konsep sulapa (sustainable landscape planning) di kawasan bersejarah kota tua tosora kabupaten wajo. Prosiding Membingkai Multikultur Dalam Kearifan Lokal Melalui Perencanaan Wilayah dan Kota, pp. 394-408. Bali: Indonesian Hindu University.

Tilaar, H. A. (1997). Pengembangan sumber daya manusia dalam era globalisasi : visi, misi, dan program aksi pendidikan dan pelatihan menuju 2020. Jakarta: Grasindo.

Utami, A. (2018). Eksplorasi sumber belajar pada rancang bangun rumah adat lampung (lamban dalom) dengan perspektif etnomatematika [Doctoral dissertation, UIN Raden Intan Lampung].

Wahyuni, A., Aji, A., Tias, W., \& Sani, B. (2013). Peran etnomatematika dalam membangun karakter bangsa. Penguatan Peran Matematika dan Pendidikan Matematika untuk Indonesia yang Lebih Baik, 1, 111-118. Yogyakarta: Universitas Negeri Yogyakarta

Yudono, A., Harisah, A., \& Sir, M. M. (2018). Sulapa eppa as the basic or fundamental philosophy of traditional architecture buginese, SHS Web of Conferences (p. 04005). EDP Sciences.

Zaenuri, Z., \& Dwidayanti, N. (2018). Menggali etnomatematika: Matematika sebagai produk budaya. PRISMA, Prosiding Seminar Nasional Matematika, pp. 471-476. 
Identifying Ethnomathematics in the Old Mosque of Tosora 